\title{
Tax Avoidance Practises and Firm-specific Characteristics: Empirical Evidence from the Egyptian Listed Companies
}

\author{
Laila Mohamed Alshawadfy AlAdwey*
}

(*) Laila AlAdwey is a lecturer in accounting, Faculty of Commerce, Tanta University.

She got her PhD in Accounting from Tanta University, Egypt in joint supervision mission with Glasgow University, UK. She also got a Certificate in Social Science Research Methods from College of Social Sciences, University of Glasgow; and Master and BCom degrees in Accounting from Tanta University, Egypt. She is FHEA Descriptor 2 as recognized from TeachBU Bournemouth University, UK. In addition, she is recognized as GTA from Learning and Teaching Centre, University of Glasgow, UK and as Certified Trainer, Training of Training (TOT), awarded from International Center for Faculty and Leadership Development, Tanta University, Egypt. Also, she is granted Special Appreciation from Arab Administrative Development Organization in the conference of Sharjah PhD Award.

Email: laila.eladawi@commerce.tanta.edu.eg 
Tax Avoidance Practises and Firm-specific Characteristics:

\section{Abstract}

Tax avoidance is the companies' action toward circumventing or mitigate their tax payment in legitimate way. Egypt suffers from higher rate of tax avoidance in the last decade due to a package of local and global events that might affect the financial stability of the Egyptian listed companies. The aim of this study is to assess the main determinants of the tax avoidance practise in the Egyptian context for the period from 2015 to 2018. To this end, the study utilizes the OLS regression with robust standard errors based on 672 firm-year observations. The results reveals that the tax avoidance practise in Egypt is a function of a set of firm-specific factors, namely financial distress, profitability, size and growth opportunities. Specifically, the companies suffering from higher financial distress have bigger tendencies to aggressively conduct their tax planning. Also, the highly profitable companies are more willing to engage in tax avoidance activities. In addition, the bigger the company's size, the higher motivation toward the tax avoidance practice. Similarly, the more potential growth opportunities companies utilize the higher the impetus to avoid the tax payment. Finally, the study could not find any association between capital intensity nor leverage and tax avoidance.

Keywords: Tax avoidance, financial distress, capital intensity, firm size, profitability, Egyptian listed companies.

الكلمات المفتاحية: التجنب الضريبي ، الضائقة المالية ، كثافة رأس المال ، حجم الثركة ،

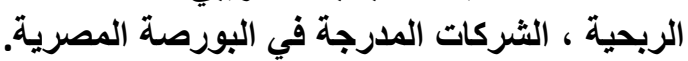

التجنب الضريبي هو إجراء تتخذه الشركات للتحايل أو التخفيف من دفع الضرائب بطريقة

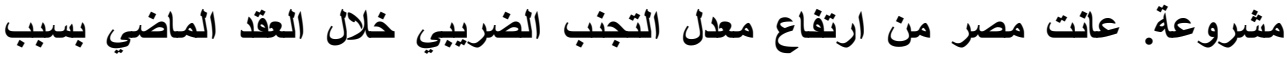
مجموعة من الأحداث المحلية والعالمية التي قد تؤثر على الاستثرار الماتي الثي للشركات

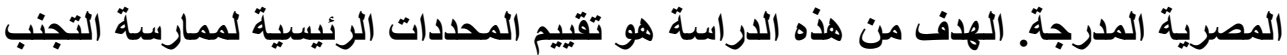

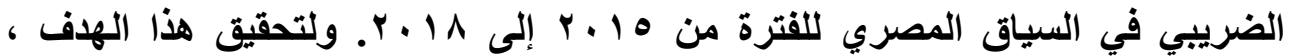
تستخدم الاراسة نموذج الإنحدارالخطي للمربعات الصغرى مع التحكم في الأخطاء

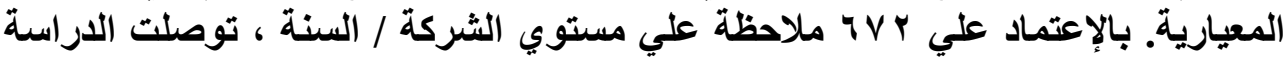
إلي أن ممارسة التجنب الضريبي في مصر هي دالة لمجموعة من العوامل الخاصة الخدة

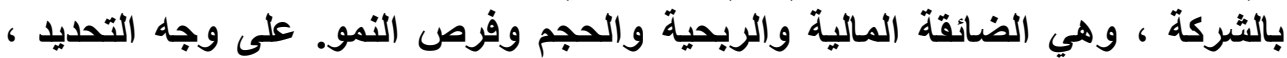

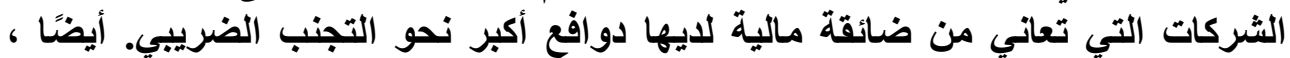
الشركات ذات الربحية العالية أكثر استعدادًا نلانخراط في في أنشطة التجنب الضبه الضريبي. بالإضافة إلى ذلك ، كلما زاد حجم الشركة ، زاد الدافع نحو ممارسة التجنب الضرئبي. وبالمثل ، كلما زادت فرص النمو المحتملة للشركة كلما زادت الرغبة نحوتجنب دفع الضرائب. أخيرًا ، لم تجد الاراسة أي ارتباط بين كثافة رأس المال أوالرافع المالي 


\section{Introduction}

Tax avoidance can be defined as all companies' initiatives to mitigate their tax payments relative to their earnings before tax (Dyreng et al. 2008, Bayar et al. 2018). It encompasses all management's actions to best utilize any weakness or shortage in the corporate tax laws and regulations to significantly reduce its explicit tax burden (Lietz, 2013 and Richardson et al., 2015a). Since taxes consume a significant amount of companies' income, they resort to tax management strategies such as tax avoidance to mitigate their payment (Ulfa et al., 2021). Tax avoidance permit companies to reduce or avoid paying their taxes in a legal and safe manner through taking the advantage of deficiencies in tax law and regulations (Napitupulu et al., 2019).

The agency theory provides a proper base for interpretating the companies' incentives to engage in tax avoidance activities. The agency theory is based on a central premise that both the agent and the principal are self-interested (Eisenhardt, 1989). The company' managers are the agent or the decision maker that would decide the policies toward tax planning activities. As the taxpayers, managers have strong incentives for tax avoidance activities since they help in mitigating the corporate tax in legitimate manner (Lanis and Richardson, 2012; Richardson et al., 2015 a; Dang and Tran, 2021). In addition, tax avoidance would help managers to boost their companies' income, maximize their bonuses and create good reputation in the shareholder's perceptions (Dang and Tran, 2021, Ulfa et al., 2021). Accordingly, the tax avoidance add value for companies' shareholders (Deef et al.,2021). On the other hand, the tax revenues are integral part in the governmental income needed for the economic expansion and for th infrastructure and investments development (Richardson et al., 2015a, Dang and Tran, 2021). Accordingly, the tax agencies, acts as the principal, are interested in maximizing the tax revenues to the extent possible (Ulfa et al 2021).

Egypt, as an emerging economy, greatly suffers from the tax avoidance activites. The gab in national tax law (Aldemrdash, 2020), the irregularities in the tax system (Ali et al.,2017), the stream of uncertainties associated with the radical economic and political events (Abdelfattah and Aboud, 
2020 and Aladwey, 2021) are all contributed such end. The Egyptian government begin series of steps toward the economic reestablishment and ensuring a fairer and stronger tax system is critical step toward this end (Elnaggar ,2020; Aladwey 2021). Egypt takes serious action toward tackling the tax avoidance activities such as the issuance of the Unified Tax Procedure Law (UTP Law), No.206 in 2020; accompanied by a set of penalties for non-compliance taxpayers and engaging in global agreements to mitigate the companies' transfer of their profit to low-income countries. All such governmental initiatives toward mitigating the tax avoidance in indicate the Egyptian government's concerns about its bad consequences on the economy as the result of cutting the tax revenue generated.

The pertinent literature around the tax avoidance within the Egyptian context examines the association between corporate governance mechanisms and CSR disclosure in relation tax avoidance (e.g., Abdelfattah and Aboud, 2020; Abd-Elmageed and Ashour, 2021); the effect of equity ownership structure on tax avoidance (Deef et al. 2021; Elesdawy and Slem, 2021) and the relationship between the tackling of tax avoidance and the spread of digital economy (Aldemrdash,2020). Beyond these previous studies, this study aims at examining the main determinants of tax avoidance relative to the firm-specific characterises of the Egyptian listed companies.

Examinig the firm specific factors that determine the practise of tax avoidance is still unsettled area in the pertinent literature subject to the contraindicated results generated. Habib et al., (2020) contend that there is no empirical evidence that indicate that the financially distressed companies would engage in tax avoidance activities to maintain cash for their own instead of swapping to tax agencies. While Lanis and Richardson (2012,2015); Richardson et al. (2015a) find positive association between the capital intensity and the tax avoidance, Maulana et al. (2018), Monika and Noviari (2021) and Ulfa et al. (2021) report non-significant association. In addition, Lanis and Richardson $(2012,2015)$ refer to the conflicting results in the literature regarding the association between the profitability and the tax avoidance. Regarding the firm size and tax avoidance, positive associations are reported by (e.g., Lanis and Richardson, 2012, Richardson et al.,2015a); while negative association are found by (e.g., Kim and Im, 
2017, Sugeng et al. 2020), and a non-significant association are reported by (e.g., Kalbuana et al., 2020; Sugeng et al., 2020; Dakhli, 2021; Ulfa et al., 2021). Also, Salhi et al. (2020) reveals a positive association between leverage and tax avoidance for French companies but report a nonsignificance association for UK companies. Similarly, the growth opportunities positively influence the tax avoidance as evidenced by (e.g., Lanis and Richardson, 2012), while a non-significant effect is found by (e.g., Dang and Tran, 2021).

Based on a sample of 170 Egyptian listed companies, the main objective of the study is to address the associations between the firm specific characteristics of financial distress; capital intensity; profitability; size; leverage and growth opportunities and the tax avoidance. Through utilizing the OLS regression with robust standard errors and subject to 672 firm-year observations around Egyptian listed companies for the period from 2015 to 2018 , the findings of this study can be summarized as follows. To begin with, a positive association is found between financial distress and tax avoidance practices. In addition, a non-significant effect of capital intensity over tax avoidance in the Egyptian context is reported. Furthermore, the profitability positively impacts the companies' intension to undertake the tax avoidance activites. Similarly, the firm size, proxied by natural logarithm of total assets, also augment the tax avoidance rate. Finally, although the companies' potential expansion has positive effect on tax avoidance, the leverage ratio has non-significance impact in this regard.

The remainder of this study is organized as follows. The second section addresses the institutional background of the tax avoidance practices in Egypt, reviews the literature around the tax avoidance determinants and develops the hypotheses. The third section describes the sample, defines the variables and explores the methodology. The fourth section discusses the descriptive statistics and the main results. The final section shows the conclusion.

\section{Literature Review and Hypotheses Development}

Reviewing the literature around the tax avoidance reveals two different views around its notion or core. The first view simply defines tax avoidance as the activities companies perform to reduce their tax payments within the legal boundaries by exploiting the holes and the weakness in the corporate 
tax law (Napitupulu et al., 2019; Dakhli, 2021; Ulfa et al., 2021). Accordingly, tax avoidance does not entitle any violation of the tax provisions and regulations (Richardson et al., 2015a). Another view of tax avoidance is provided by Aldemrdash, (2020) that take into account the distinction between the legal and the unethical tax behaviors. That is, although the tax avoidance practices are conducted under the legal purview, it is considered unethical behavior since it is accompanied by taking the advantage of the gabs or the variations in interpreting the tax law (Aldemrdash, 2020). In similar vein, Abd-Elmageed and Ashour (2021) argue that the tax avoidance has two sides, that is it might be positively perceived as a well-organized mechanism to plan tax activities and manage its timely payment or negatively interpreted as actions to erode the tax payment by exploiting any gap in the corporate tax law.

Table I summarized the main determinants of tax avoidance in the pertinent literature. As demonstrated in Table I, it can be said that the literature is full of different initiatives to assess the main determinants of tax avoidance within the different settings, whether in developed countries such as \{Australia (e.g., Richardson et al., 2015a); USA (e.g., Richardson et al., 2015 b)\}; or in developing countries such as \{Korea (e.g., Kim and Im, (2017); Indonesia (e.g., Sugeng et al. 2020; Kalbuana et al. 2020) and so on...\}. However, tracking such initiatives reveal the wide contradiction among different studies regarding the main factors that influence the tax avoidance practice as well as the significance and the direction of the association between such factors and tax avoidance. The following subsection highlights the key features of the tax avoidance practice within the Egyptian context. Afterwards, the next subsection reviews the literature around the examined factors that may affect the tax avoidance practices and postulates the main hypotheses. 
Table I The Determinants of Tax Avoidance

\begin{tabular}{|c|c|c|c|}
\hline Authors & Examined factors & Sample & Main Findings \\
\hline $\begin{array}{l}\text { Richardson } \\
\text { et al. } \\
(2015 a)\end{array}$ & $\begin{array}{l}\text { The aim is to address } \\
\text { the impact of the } \\
\text { global financial crisis } \\
\text { in } 2008 \text { on the } \\
\text { association between } \\
\text { financial distress and } \\
\text { tax avoidance in } \\
\text { Australia. }\end{array}$ & $\begin{array}{l}\text { The sample } \\
\text { encompass } 203 \\
\text { listed } \\
\text { Australian } \\
\text { companies for } \\
\text { the period from } \\
2006 \text { to } 2010 \text {. }\end{array}$ & $\begin{array}{l}\text { The results indicate a positive association } \\
\text { between financial distress and tax } \\
\text { avoidance. Also, the results reveal the } \\
\text { significance of such association during } \\
\text { the global financial crisis in } 2008 \text {. }\end{array}$ \\
\hline $\begin{array}{l}\text { Richardson } \\
\text { et al. } \\
(2015 b)\end{array}$ & $\begin{array}{l}\text { The aim is to assess } \\
\text { the association of the } \\
\text { financial distress and } \\
\text { tax aggressiveness } \\
\text { during the period of } \\
\text { global financial crisis. } \\
\text { with tax }\end{array}$ & $\begin{array}{l}\text { The sample } \\
\text { includes } 12376 \\
\text { firm-year } \\
\text { observations for } \\
\text { US listed } \\
\text { companies over } \\
\text { 2006-2010. }\end{array}$ & $\begin{array}{l}\text { A positive association is reported between } \\
\text { the proxies of financial distress and } \\
\text { global crisis form one set and tax } \\
\text { aggressiveness from the other set. }\end{array}$ \\
\hline $\begin{array}{l}\text { Kim and Im, } \\
\text { (2017) }\end{array}$ & $\begin{array}{l}\text { The aim is to identify } \\
\text { the financial } \\
\text { determinants for tax } \\
\text { avoidance in Korea. }\end{array}$ & $\begin{array}{l}\text { The sample } \\
\text { covered } 18,954 \\
\text { firm-year } \\
\text { observations of } \\
\text { the Korean } \\
\text { listed } \\
\text { companies for } \\
\text { the period from } \\
2011 \text { to } 2013 \text {. }\end{array}$ & $\begin{array}{l}\text { The results indicate that the corporate tax } \\
\text { avoidance is mainly associated with } \\
\text { certain firm specific factors such as } \\
\text { companies 'size, profitability leverage, } \\
\text { operating cash flow, capital intensity, } \\
\text { R\&D intensity and growth rate. }\end{array}$ \\
\hline $\begin{array}{l}\text { Tilehnouei } \\
\text { et al. (2018) }\end{array}$ & $\begin{array}{l}\text { The aim is to } \\
\text { investigate the effect } \\
\text { of financial distress on } \\
\text { tax avoidance. }\end{array}$ & $\begin{array}{l}\text { The sample } \\
\text { includes the } \\
\text { listed } \\
\text { companies in } \\
\text { Tehran stock } \\
\text { exchange } \\
\text { during the } \\
\text { period from } \\
2003 \text { to } 2013 \text {. }\end{array}$ & $\begin{array}{l}\text { The results indicate the non-significance } \\
\text { influence of the financial distress on tax } \\
\text { avoidance. }\end{array}$ \\
\hline $\begin{array}{l}\text { Bayar et al. } \\
\text { (2018) }\end{array}$ & $\begin{array}{l}\text { The aim is to assess } \\
\text { the association } \\
\text { between tax avoidance } \\
\text { and financial distress } \\
\text { in the light of the } \\
\text { surrounding corporate }\end{array}$ & $\begin{array}{l}\text { The total } \\
\text { sample } \\
\text { encompasses } \\
35,000 \text { firm- } \\
\text { year } \\
\text { observations }\end{array}$ & $\begin{array}{l}\text { A positive association between tax } \\
\text { avoidance and financial distress in the } \\
\text { case of poor governance structure. } \\
\text { However, in the case of well-organized } \\
\text { governance setting, tax avoidance does } \\
\text { not negatively affect on the financial }\end{array}$ \\
\hline
\end{tabular}


Tax Avoidance Practises and Firm-specific Characteristics:

\begin{tabular}{|c|c|c|c|}
\hline & governance structure. & $\begin{array}{l}\text { from } 1990 \text { to } \\
2015 \text { based on } \\
\text { different } \\
\text { international } \\
\text { countries. }\end{array}$ & constraints. \\
\hline $\begin{array}{l}\text { Sugeng et } \\
\text { al. (2020) }\end{array}$ & $\begin{array}{l}\text { The paper aim is to } \\
\text { assess the association } \\
\text { between the } \\
\text { companies' capital and } \\
\text { inventory intensity; } \\
\text { size; risk and political } \\
\text { connections on tax } \\
\text { aggressiveness. }\end{array}$ & $\begin{array}{l}\text { The sample } \\
\text { cover the } \\
\text { Indonesian } \\
\text { manufacturing } \\
\text { listed } \\
\text { companies for } \\
\text { the period from } \\
2015 \text { to } 2017\end{array}$ & $\begin{array}{l}\text { The paper concludes a positive effect of } \\
\text { both capital intensity and political } \\
\text { connection on tax avoidance and non- } \\
\text { significance correlation between } \\
\text { inventory intensity, companies' size and } \\
\text { risk, and tax aggressiveness. }\end{array}$ \\
\hline $\begin{array}{l}\text { Kalbuana et } \\
\text { al. (2020) }\end{array}$ & $\begin{array}{l}\text { This paper aims at } \\
\text { examining the main } \\
\text { determinants of tax } \\
\text { avoidance in relation } \\
\text { to companies' capital } \\
\text { intensity, size, and } \\
\text { leverage. }\end{array}$ & $\begin{array}{l}\text { The sample } \\
\text { listed } \\
\text { companies in } \\
\text { Jakarta Islamic } \\
\text { Index (JII) for } \\
\text { the period of } \\
2015 \text { to } 2019 \text {. }\end{array}$ & $\begin{array}{l}\text { The results show that tax avoidance is } \\
\text { positively associated with capital } \\
\text { intensity; negatively associated with } \\
\text { leverage and not significantly related to } \\
\text { companies' size. }\end{array}$ \\
\hline $\begin{array}{l}\text { Ulfa et al. } \\
\text { (2021) }\end{array}$ & $\begin{array}{l}\text { The aim is to sssess } \\
\text { the effect of CEO } \\
\text { tenure, capital } \\
\text { intensity, and } \\
\text { company size on tax } \\
\text { avoidance }\end{array}$ & $\begin{array}{l}\text { The sample } \\
\text { includes } \\
\text { manufacture } \\
\text { listed } \\
\text { companies on } \\
\text { Indonesia Stock } \\
\text { Exchange } \\
\text { (IDX). for the } \\
\text { year 2019. }\end{array}$ & $\begin{array}{l}\text { The results indicate that although the } \\
\text { CEO tenure positively influence on tax } \\
\text { avoidance, both the capital intensity and } \\
\text { firm size are not affecting companies' } \\
\text { intention to avoid paying their due taxes. }\end{array}$ \\
\hline $\begin{array}{l}\text { Darsani and } \\
\text { Sukartha } \\
(2021)\end{array}$ & $\begin{array}{l}\text { The aim is to examine } \\
\text { the influence of four } \\
\text { main variables, } \\
\text { namely institutional } \\
\text { ownership, } \\
\text { profitability, leverage } \\
\text { and capital intensity } \\
\text { on tax avoidance. }\end{array}$ & $\begin{array}{l}\text { The sample } \\
\text { covers the } \\
\text { Indonesian } \\
\text { companies } \\
\text { belongs to the } \\
\text { mining sector } \\
\text { for the period } \\
\text { from } 2015 \text { to } \\
2019 \text {. }\end{array}$ & $\begin{array}{l}\text { The results indicate the positive influence } \\
\text { of companies' profitability and capital } \\
\text { intensity on tax avoidance; the negative } \\
\text { effect of the institutional ownership on } \\
\text { tax avoidance and the non-significant } \\
\text { effect of leverage on tax avoidance. }\end{array}$ \\
\hline
\end{tabular}




\subsection{Institutional background in the Egyptian context}

Tax avoidance is one of the main gauntlets that face the Egyptian regulators and policymakers in the contemporary era ${ }_{1}$. According to Aldemrdash (2020), based on a report issued by the Network Justice Tax, the cost of tax avoidance is estimated to approximately be 68 milliards in 2012 which constitutes one-third of the tax revenues generated of the same year. In addition, Gad et al., (2019) indicate that the tax avoidance practice is a primary factor behind the low tax revenue in Egypt as evidenced by the world bank report which manifests that the tax revenue is approximately $12.5 \%$ of the GDP relative to $15.4 \%$ in the OECD countries. In addition, based on data from the Egyptian listed firms for the period 2007-2016, Abdelfattah and Aboud (2020) indicate Egyptian listed companied may resort to obsessive CSR disclosure to conceal their tax avoidance practise and create a refined image of the companies in the public perception.

It is possible to address a lot of facets for tax avoidance in Egypt. First, the tax haven is one of the common practices in Egypt $_{2}$. It means the companies' transfer of their profit to other countries that estimate lower income tax rates (Deef et al., 2021). Second, the tax arbitrage gives some room for practising the tax avoidance in such companies would utilize the marginal tax rate by transferring their high taxable income to lower taxable income to take the advantage of lower tax rate (Ali et al. 2017 and Aldemrdash, 2020, Deef et al. 2021). The third example is the tax postponing to take the advantage of variation in the time value of money across different periods (Aldemrdash, 2020).

The diffusion of such practices in Egypt may be attributed to many factors as follows. First, the Egyptian companies may exploit gabs in the national law that permits them to establish secret offshore financial centres in lower tax countries so that they can avoid paying higher tax estimated according to the Egyptian corporate tax law (Aldemrdash, 2020). Second, the lack of well-organized documentation for tax statements for a huge number of

${ }^{1}$ https://aps.aucegypt.edu/en/articles/556/why-cant-egypt-collect-taxes-efficiently 
taxpayers ${ }_{1}$. Third, the success of any tax system is mainly dependent on the nature of the economic activities subject to this system (Aldemrdash, 2020) as well as the stability in its political system (Lietz, 2013). Although, ccompared to other countries in MENA region, the Egyptian Stock Exchange (EGX) is one the highly matured stock markets in the Middle East (Elsayed and Wahba, 2013), it suffers from many irregularities. That is, the Egyptian stock market is characterized by week investor protection and high level of corruption (Abd-Elmageed and Ashour,2021) as well as the dominance of the institutional owners over the equity shareholding (ElMasry, 2010). In addition, Egypt has passed a critical period at the political level since the Egyptian' revolution in 2011, followed by another revolution in 2013 (Aladwey, 2021).

The Egyptian governments take radical actions toward tackling the diffusion of tax avoidance to increase its tax income revenue. This could be evidenced by the OECD/G20 inclusive framework that indicate that Egypt is one from 139 countries that recently issue fifteen corrective actions to mitigate the tax avoidance activities and settling the contemporary tax challenges $^{2}$. In addition, in 2020, the Egyptian governmet releases the UTP Law, No.206 for the purpose of amending the deficiencies in the income tax law $^{3}$. For example, the Egyptian Tax Authority (ETA) permits the taxpayers to submit their tax statements within one year from the original submission date, otherwise they would lose their right of submission and would be penalized by being regarding as tax evader or getting a tax audit alert from ETA $^{4}$. Furthermore, the UTP Law originates a series of financial penalties in the of the companies' non-compliance with such laws ${ }^{5}$ Additionally, with the cooperation of the OECD, the Egyptian Ministry of Finance has recently engaged in a European Union-funded (EU-funded) project that partially aim

\footnotetext{
${ }^{1}$ The same as 1 .

2 https://english.ahram.org.eg/News/416425.aspx

${ }^{3} \mathrm{https} / / / \mathrm{www} . \mathrm{pwc} . c 0 \mathrm{~m} / \mathrm{m} 1 / \mathrm{en} /$ services/tax/me-tax-legal-news/2020/egyptian-governmentissues-unified-tax-procedures-law-no-206-2020.html

${ }^{4}$ The same as 5 .

${ }^{5}$ https://taxsummaries.pwc.com/egypt/corporate/tax-administration
} 
at enhancing more transparent tax reporting and helping the ETA to handle the aggressive tax planning schemes taken by the Multi-National Enterprises (MNEs) ${ }^{1}$.

\subsection{Hypotheses Development}

\subsubsection{Financial Distress and Tax Avoidance}

Financially distress companies are in badly need to minimize their cash outflows, and since the tax expenses consume a significant portion of companies' outflows, these companies become more inclined toward tax avoidance practices (Richardson et al. 2015a). According to Habib et al. (2020), companies suffering financial distress would engage in tax planning activities as a root to tackle such distress. Also, Richardson et al. (2015a) argue that the financial distressed companies may accentuate the importance of actions utilized to reduce their current income tax since such actions may be considered as an auxiliary strategy to pass this highly tension period.In addition, from cost versus benefit perspective, companies within the financial distress periods may be more willing to undertake actions such as tax avoidance that were previously considered as risky or costly as long as such actions are accompanied with higher potential benefits (Dang and Tran, 2021, Richardson et al. 2015a).

Subject to the International Monetary Fund (IMF)'s report issued in 2020, the Egyptian economy struggle to survive as the result of the variant political instability in the last decade. Beyond 2011, Egypt has witnessed highly tension period that is congested of many radical events at both economic and political levels, such as the two Egyptian revolutions in 2011 and 2013, the devaluation of the Egyptian pound in 2014 and the critical economic recovery initiatives and so on (Aladwey, 2021). Accordingly, subject to the atmosphere of the aforementioned instability in the economiy, it is expected that companies suffering from financial instability are more

\footnotetext{
${ }^{1}$ https://www.oecd-ilibrary.org/sites/b41691ae-

en/index.html?itemId=/content/component/b41691ae-en
} 
oriented toward adopting more risky strategies and engaging in tax aggressiveness. Thus, the first hypothesis can be formulated as follows:

$\mathrm{H}_{1}$ : The financial distress is positively associated with tax avoidance for Egyptian listed companies.

\subsubsection{Capital Intensity and Tax Avoidance}

The capital intensity shows the percentage of fixed assets companies own relative to their total assets (Kalbuana et al., 2020). The depreciation expenses associated with the fixed assets would be deducted from the companies' total revenue generated, thus the higher the percentage of fixed assets and their corresponding depreciation expenses, the lower the taxable income and the tax rate applied (Kalbuana et al. 2020; Darsani and Sukartha, 2021). Based on the agency theory, the potential conflict of interest between the tax authorities and the taxpayers would compel companies' managers to manipulate their taxable income that is, for example, by taking the advantage of their depreciation expense to reduce their tax burden (Richardson et al. 2015a, Ulfa et al. 2021). Since managers are the decision makers, they would choose the accelerated depreciation methods that augment the depreciation expense in accordance with the useful life of the fixed asset (Richardson et al. 2015a). Thus, the higher the companies' capital intensity, the more their chance to mitigate the taxable income and in turn the tax payment. In addition, the pertinent literature provides empirical evidence of the positive association between capital intensity and tax avoidance (e.g., Lanis and Richardson, 2012,2015; Richardson et al. 2015a). Accordingly, the second hypothesis can be formulated as follow:

$\mathrm{H}_{2}$ : The capital intensity is positively associated with tax avoidance for Egyptian listed companies.

\subsubsection{Profitability and Tax Avoidance}

Based on agency theory premises, there a proper conflict between the tax authority (the principal) and the taxpayer or the company (the agent). 
Although the tax authorities are pursuing to maximize the tax revenue to the extent possible, the taxpayer are searching for all the appropriate avenues to lessen their tax payments and at the same time maintain higher profit figures (Darsani and Sukartha, 2021). Consistently, Lanis and Richardson (2012) provide empirical evidence that the highly profitable companies have higher tendency toward tax avoidance practices to minimize their tax burdens. Similarly, Irianto et al. (2017) indicate a positive effect of ROA on tax avoidance. In addition, Kim and Im (2017) argue that companies that achieve higher profitability are more likely to resort to earning smoothing activities to avoid the payment of the corporate taxes. Furthermore, based on a sample of Egyptian listed companies, Abd-Elmageed and Ashour (2021) indicate that highly profitable companies tend to search for the possible avenues to avoid the tax payment. Thus, it is expected that the relationship between companies' profitability and tax avoidance as follows:

$\mathrm{H}_{3}$ : The companies' profitability is positively associated with tax avoidance for Egyptian listed companies.

\subsubsection{Firm size and Tax Avoidance}

The literature provides three mixed results regarding the association between firm size and tax avoidance activities as follows. The first strand of research argues a positive association between companies' size and tax avoidance that is the big size companies are more willing to engage in tax avoidance activities. Lanis and Richardson (2012) conclude that the larger the companies' size, the more aggressive the tax policy. Likewise, relative to the small size companies, Richardson et al. (2015a) argue that the financial resources and political power possessed by larger companies enable them to find several avenues toward reducing their tax obligations, thus they are more likely to be tax avoidant. In contrast, the second strand of research indicates the negative influence of companies' size on the tax avoidance. Kim and Im (2017) contend that small size companies are more oriented to capture the tax avoidance policies. As noted by Sugeng et al. 
(2020), the negative association between the companies' size and tax avoidance may underpins the political power theory argument that the large size companies have political power that help them to suitably conduct tax planning initiatives to reduce taxes and to achieve optimal tax reduction. Accordingly, large size companies have lower incentives toward tax avoidance activities (Sugeng et al., 2020). The third strand of research indicate that the companies' size has no significant effect on tax avoidance (e.g., Kalbuana et al., 2020; Sugeng et al., 2020; Dakhli, 2021; Ulfa et al., 2021). Accordingly, the association between companies' size and tax avoidance is left without identifying the proper direction as follow:

$\mathrm{H}_{4}$ : Firm size is significantly associated with tax avoidance for Egyptian listed companies.

\section{Research Design}

\subsection{Sample and Data}

The sample encompasses the Egyptian listed companies in EGX stock market for the period from 2015 to 2018. Panel A, Table II summarize the sample selection process as follows. First, similar to Ramadan (2015); Shahwan (2015) and Aladwey (2021), the financial companies (39 companies) are excluded from the sample due to their unique regulations for the financial reporting and disclosure. Second, the companies with missing data (5 companies) are also excluded from the target sample. Data required for the measurement of the main variables utilized in this paper are collected the S\&P Capital IQ database. Subject to the data availability, the sample covers four fiscal years from 2015 to 2018. The final sample includes 170 non-financial listed companies that yields 672 firm-year observations. Panel $\mathrm{B}$, Table III demonstrates the categorization of the observations according to the different industrial sectors within the Egyptian market. 
Table II. Sample Selection Criteria

\begin{tabular}{|c|c|c|c|c|c|c|c|c|c|c|}
\hline \multicolumn{9}{|c|}{ Panel A: Sample selection criteria } & \multicolumn{2}{|c|}{$\begin{array}{c}\text { No. of } \\
\text { companies }\end{array}$} \\
\hline \multicolumn{9}{|c|}{ The whole number of the Egyptian listed companies between 2015 to 2018} & \multicolumn{2}{|c|}{214} \\
\hline \multicolumn{9}{|c|}{ (-) Financial companies } & \multicolumn{2}{|c|}{39} \\
\hline \multicolumn{9}{|c|}{ Subtotal } & \multicolumn{2}{|c|}{175} \\
\hline \multicolumn{9}{|c|}{ (-) Companies with missing data } & \multicolumn{2}{|c|}{5} \\
\hline \multicolumn{9}{|c|}{ Final sample } & \multicolumn{2}{|r|}{170} \\
\hline \multicolumn{9}{|c|}{ Number of observations } & \multicolumn{2}{|r|}{672} \\
\hline \multicolumn{11}{|c|}{ Panel B: Sample according to the different industrial sectors } \\
\hline $\begin{array}{c}\text { Communication } \\
\text { Services }\end{array}$ & $\begin{array}{c}\text { Consumer } \\
\text { Discretionary }\end{array}$ & $\begin{array}{l}\text { Consumer } \\
\text { Staples }\end{array}$ & Energy & $\begin{array}{c}\text { Health } \\
\text { Care }\end{array}$ & Industrials & $\begin{array}{l}\text { Information } \\
\text { Technology }\end{array}$ & Materials & $\begin{array}{c}\text { Real } \\
\text { Estate }\end{array}$ & Utilities & Total \\
\hline 16 & 124 & 120 & 8 & 60 & 92 & 12 & 126 & 110 & 4 & 672 \\
\hline 2.38 & 18.45 & 17.86 & 1.19 & 8.93 & 13.69 & 1.79 & 18.75 & 16.37 & 0.60 & 100 \\
\hline
\end{tabular}

\subsection{Variables Measurement}

The aim of the paper is to identify the main determinants of the tax avoidance practise in Egypt. Table III shows the measurement of the different utilized variables. The dependent variable is tax avoidance (TAX). Following Dakhli (2021), Deef et al. (2021), and Ulfa et al., (2021); TAX is measured as the current tax expenses deflated on the income before taxes. According to Lanis and Richardson (2012) and Dakhli (2021), TAX is the commonly used measure for tax avoidance in the pertinent literature since it demonstrates the whole set of tax avoidance strategies, whether permanent or temporary. It measures the companies' ability to mitigate their tax payment figures compared to the earning before tax (Lietz, 2013).

The independent variables are financial distress, capital intensity, financial performance and firm size. First, to evaluate the companies' likelihood of financial bankruptcy, we employee the revised Altman Z-score model (Altman et al. 1995). According to Jahan and Kabir (2019) and Shahwan and Habib (2020), the Altman Z-score model is one of the most popular models to assess the financial distress, that is appropriate for both manufacturing and non-manufacturing companies, as well as for companies working within emerging markets. The modified Z-score can be calculated using the following mathematical equation (Altman and Hotchkiss,2006, p. 267): 


$$
\begin{gathered}
\mathrm{Z} \text {-score }=3.25+6.56(X 1)+3.26(X 2)+6.72(X 3)+1.05(X 4) \\
\text { where }
\end{gathered}
$$

$X 1=$ working capital/total assets

$X 2=$ retained earnings/total assets

$X 3=$ income before taxes and interest/total assets

$X 4$ = book value of equity/total liabilities

Driven from Altman (1995) and Altman and Hotchkiss (2006, p. 268), the interpretations of the utilized Z-scores can be summarized as follows; the values of $\mathrm{z}$-score greater than 5.85 demonstrate companies away from the bankruptcy risk or in the safe area; values between 4.15 and 5.85 indicates the companies' likelihood of bankruptcy or a gray area and values less than 4.15 means that companies are financially distressed or in distress zone. Second, the capital intensity (CAPINT) is measured as the companies' total fixed assets deflated by total assets (Prawati1 and Hutagalung, 2021 and Ulfa et al., 2021). Due to the accelerated depreciation expenses relative to total assets, it is expected that CAPINT positively influences TAX (Lanis and Richardson, 2015). Third, the companies' financial performance is measured using return on asset (ROA). It is calculated as the companies' net income divided by the total assets (Salhi et al., 2020; Darsani and Sukartha 2021). Fourth, similar to Salhi et al. (2020); Aladwey (2021) and Dakhli, (2021), the natural logarithm of total assets is employed as a proxy of the companies' size (SIZE).

In order to improve the predication accuracy of the regression model, the paper utilize two firm-specific factors as the control variables. First the financial leverage is used to control for the variation in the companies' risk (LEV). It is calculated as long-term debt divided by total equity (Lanis and Richardson, 2012, 2015). Salhi et al. (2020) indicates a positive association between LEV and TAX for French companies, while a non-significant association is found for UK companies. In addition, while Lanis and Richardson (2012) report a nonsignificant effect of LEV on TAX, Lanis and Richardson (2015) report a significant positive effect, implying that those companies that are mainly utilizing debt financing rather than equity financing would resort to the tax deductibility of the interest payments to satisfy their tax avoidance incentives. Accordingly, subject to these mixed findings, the direction of the association between LEV and TAX could not 
be predicated. Second, the companies' growth opportunities are proxied using the market to book ratio, MTB (Richardson et al., 2015 a,b). Similar to Dang and Tran (2021) and Darsani and Sukartha (2021), MTB is calculated as the market capitalization of outstanding shares divided by the equity book value.

Table III The EmpiricalModels and the Variables' Definitions

\begin{tabular}{|c|c|c|}
\hline \multicolumn{3}{|c|}{ 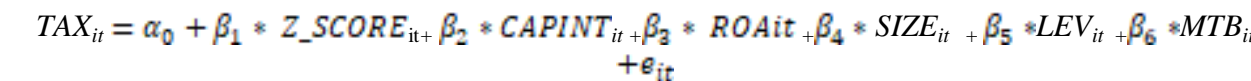 } \\
\hline \multicolumn{3}{|c|}{ Dependent Variable } \\
\hline $\begin{array}{l}\text { Tax avoidance } \\
\text { (TAX) }\end{array}$ & $\begin{array}{l}\text { It is calculated as the total tax } \\
\text { expense divided by the pre-tax } \\
\text { income. }\end{array}$ & $\begin{array}{l}\text { Richardson et al. (2015a). } \\
\text { Salhi et al. (2020) } \\
\text { Dakhli, (2021) } \\
\text { Darsani and Sukartha (2021) } \\
\text { Trisanti (2021) } \\
\text { Ulfa et al. (2021) }\end{array}$ \\
\hline \multicolumn{3}{|c|}{ Independent Variables } \\
\hline $\begin{array}{l}\text { Financial distress } \\
\text { (Z_SCORE) }\end{array}$ & $\begin{array}{l}\text { A proxy of companies' financial } \\
\text { distress as measured by Altman } \\
\text { and Hotchkiss (2006)'s model. }\end{array}$ & $\begin{array}{l}\text { Altman and Hotchkiss (2006) } \\
\text { Jahan and Kabir (2019) } \\
\text { Ikpesu (2019) } \\
\text { Shahwan and Habib (2021) }\end{array}$ \\
\hline $\begin{array}{l}\text { Capital intensity } \\
\text { (CAPINT) }\end{array}$ & $\begin{array}{l}\text { A proxy of companies' capital } \\
\text { intensity. It is calculated as total } \\
\text { fixed assets scaled by total } \\
\text { assets. }\end{array}$ & $\begin{array}{l}\text { Darsani and Sukartha (2021) } \\
\text { Trisanti (2021) } \\
\text { Prawati } 1 \text { and Hutagalung (2021) } \\
\text { Ulfa et al. (2021) }\end{array}$ \\
\hline Profitability (ROA) & Net Income/ Total Asset & $\begin{array}{l}\text { Salhi et al. (2020) } \\
\text { Darsani and Sukartha (2021) } \\
\text { Dakhli (2021) } \\
\text { Trisanti (2021) }\end{array}$ \\
\hline Firm Size (SIZE) & Log of Total Assets & $\begin{array}{l}\text { Salhi et al. (2020) } \\
\text { Dang and Tran (2021) } \\
\text { Dakhli, (2021) } \\
\text { Trisanti (2021) } \\
\text { Ulfa et al. (2021) }\end{array}$ \\
\hline \multicolumn{3}{|c|}{ Control Variables } \\
\hline Leverage (LEV) & $\begin{array}{l}\text { It is measured by deflating the } \\
\text { long-term debt by the total } \\
\text { assets. }\end{array}$ & $\begin{array}{l}\text { Lanis and Richardson, (2012,2015) } \\
\text { Richardson et al. (2015a). } \\
\text { Kalbuana et al. (2020) }\end{array}$ \\
\hline $\begin{array}{l}\text { The growth } \\
\text { opportunities (MTB) }\end{array}$ & $\begin{array}{l}\text { The market value of shareholder } \\
\text { equity/book value of } \\
\text { shareholder }\end{array}$ & $\begin{array}{l}\text { Richardson et al. (2015a,b). } \\
\text { Dang and Tran (2021) } \\
\text { Darsani and Sukartha (2021) }\end{array}$ \\
\hline
\end{tabular}




\subsection{Regression Model Specification}

The dataset encompasses 672 firm-year observation for the period from 2015 to 2018. In order to choose the appropriate regression model that accurately capture the features of the dataset, the paper follow the procedural approach of Dougherty (2011, p.527). Panel A, Table IV shows the tests conduct to identify the utilized regression model. To begin with, the Breusch and Pagan Lagrangian multiplier (LM) test is employed to compare the existence of the random effect versus to the Ordinary Least Squares (OLS) regression (Park, 2011). At the significance level of 1\%, the results reveal that the null hypothesis of the LM test need to be rejected (pvalue $<0.000$ ). Accordingly, the random effect model is better than the OLS model (Park, 2011). As a further step, the Hausman specification test is used to address the random effect relative to the fixed effect (Dougherty, 2011 and Park, 2011). The p-value of Hausman test is 0.010 which is lower than the significance threshold of $1 \%$, implying that fixed effect model is preferred model than random effect. Finally, the fixed effect model is contrasted against to OLS using the F-test. At all significance level, the results indicate the null hypothesis of F-test is accepted (the p-value < 0.663 ), suggesting that the superiority of OLS over fixed effect model.

\section{Table IV Tests Conducted for Model Specification and OLS assumption}

Testifying

\begin{tabular}{|c|c|c|c|c|c|}
\hline \multicolumn{6}{|c|}{ Panel A Model Specification Tests } \\
\hline \multirow{2}{*}{$\begin{array}{c}\text { Test / } \\
\text { Results }\end{array}$} & $\begin{array}{l}\text { Random Effect } \\
\text { Test }\end{array}$ & \multicolumn{2}{|c|}{$\begin{array}{c}\text { Random Versus Fixed Effect } \\
\text { Hausman Test }\end{array}$} & \multicolumn{2}{|c|}{$\begin{array}{c}\text { Time-Fixed Effect Test } \\
\text { F-Test }\end{array}$} \\
\hline & $\begin{array}{l}\text { Prob }>\text { chibar2 }= \\
0.000^{\star}\end{array}$ & \multicolumn{2}{|c|}{ Prob $>$ chi2 $=0.010^{\star}$} & \multicolumn{2}{|c|}{ Prob $>F=0.663$} \\
\hline \multicolumn{6}{|c|}{ Panel B: Assumption of OLS Tests } \\
\hline \multirow[t]{5}{*}{$\begin{array}{l}\text { Test / } \\
\text { Results }\end{array}$} & $\begin{array}{l}\text { Test for Normality } \\
\text { Shapiro-Wilks } \\
\text { Test }\end{array}$ & $\begin{array}{c}\text { Test for } \\
\text { heteroskedasticity } \\
\text { Breusch-Pagan/Cook- } \\
\text { Weisberg }\end{array}$ & $\begin{array}{c}\text { Ramsey } \\
\text { RESET test }\end{array}$ & \multicolumn{2}{|l|}{ Link test } \\
\hline & \multirow[t]{4}{*}{ Prob $>z=0.000$} & \multirow[t]{4}{*}{ Prob $>$ chi2 $=0.084$} & \multirow{4}{*}{$\begin{array}{l}\text { Prob }>\text { F }= \\
0.455\end{array}$} & Items & $P>|t|$ \\
\hline & & & & _hat & $0.001^{*}$ \\
\hline & & & & hatsq & 0.808 \\
\hline & & & & _cons & 0.845 \\
\hline
\end{tabular}


Panel B, Table IV shows the additional tests conducted to justify the validation of the assumption of OLS model. First, the asymptotic significant value of 0.770 for the Shapiro-Wilks Test is greater than the identified significance levels of $1 \%$, thus the dataset demonstrates the normal distribution pattern. Second, the Breusch-Pagan/Cook-Weisberg test for heteroskedasticity reveals the non-existence of heteroscedasticity in the regression model since the $\mathrm{p}$-value $<0.084$ is higher than the significance levels identified. Third, the Ramsey RESET test (the p-value<0.455) and the check for model specification errors is conducted through Linktest command (p-value of _hatsq is $<0.808$ ) and, at the $1 \%$ thresholds, the results indicate the regression model is appropriately specified. Finally, following Habbash et al., (2013) and Raweh et al., (2021), the paper addresses the use of the robust standard error version of OLS regression since it is more convenient in handling any potential effect of the autocorrelation.

\section{Results \& Discussion}

\subsection{Descriptive Analysis and correlation matrix}

Table V shows the descriptive statistics for the utilized variables (mean, standard deviation, median, minimum, and maximum). In order to exclude any extreme values that may affect the analysis of the dataset, all variables are winsorized at $1 \%$ and $99 \%$ percentiles. Similar to Abdelfattah and Aboud (2020), all negative values for TAX at firm-year level are deleted and the rest values are winsorized. The minimum level of tax avoidance practice (TAX) for the Egyptian listed companies is 0.001 while the maximum value is 0.899 with average mean of 34.3 . This result is compatible with the figures reported by Deef et al. (2021) who indicates that the average of TAX for Egyptian companies listed in the Egyptian Stock Exchange 100 (EGX 100) over the period from 2015 to 2019 is 34.8, indicating the tendency of Egyptian companies to pay their tax burden. The proxy of the financial distress, (Z-Score) is ranged between 5.49 and 13.07. Similar to the results of Ramadan (2017), the results reveal a low standard deviation of Z-Score of 2.34. This implies the minor variation in the degree 
of the financial distress for the examined companies. The CAPINT for Egyptian listed companies is ranged from 9.3 percent to 79.7 percent with dispersion rate of 23.8 percent. The average capital intensity (CAPINT) is 42.1 percent, demonstrating that more than one-third of the total assets owned by Egyptian companies are categorized as fixed assets.

Regarding the control variables, the span of the profitability (ROA) of the Egyptian non-financial listed companies is between -5.3 percent to 16.7 percentwith an average mean of 4.8 percent. This result may indicate the wide variation in the financial performance between the companies in the sample. The standard deviation of companies' size (SIZE) is 6.4 percent ranged from 19.1 percent to 38.7 percent. The financial leverage (LEV) is fluctuated around 0.1 percent where the lowest level 0 percent and the highest level is 1.8 percent. Finally, the mean value of companies' growth avenues (MTB) is 2.14 with the range slot between .11 and 7.72.

Table V The Descriptive Statistics

\begin{tabular}{|c|l|l|l|l|l|l|}
\hline \multicolumn{7}{|c|}{ Panel A: Summary Statistics for the Variables } \\
\hline & Obs & Mean & Std. Dev. & Median & Min & Max \\
\hline TAX & 672 & .343 & .287 & .343 & 0.001 & .899 \\
\hline Z_SCORE & 672 & 9.04 & 2.34 & 8.96 & 5.49 & 13.07 \\
\hline CAPINT & 672 & .421 & .238 & .380 & .093 & .797 \\
\hline ROA & 672 & .048 & .066 & .037 & -.053 & .167 \\
\hline SIZE & 672 & 2.88 & .64 & 2.89 & 1.91 & 3.87 \\
\hline LEV & 672 & .04 & .06 & .0011 & 0 & .18 \\
\hline MTB & 672 & 2.14 & 2.48 & 1.14 & .11 & 7.72 \\
\hline
\end{tabular}

Table VI shows the correlation matrix and multicollinearity results for the main variables. Panel A, Table VI indicate that the multicollinearity problems do not matter, that is there is no relationship between the independent variables since the correlation is less than 0.8. Furthermore, Panel B, Table VI reveals that the variance inflation factors (VIFs) for the independent variables are all less than 10 and the tolerance levels are more than 0.2 , implying that the non-presence of multicollinearity concerns. 
Table VI The Correlation Results

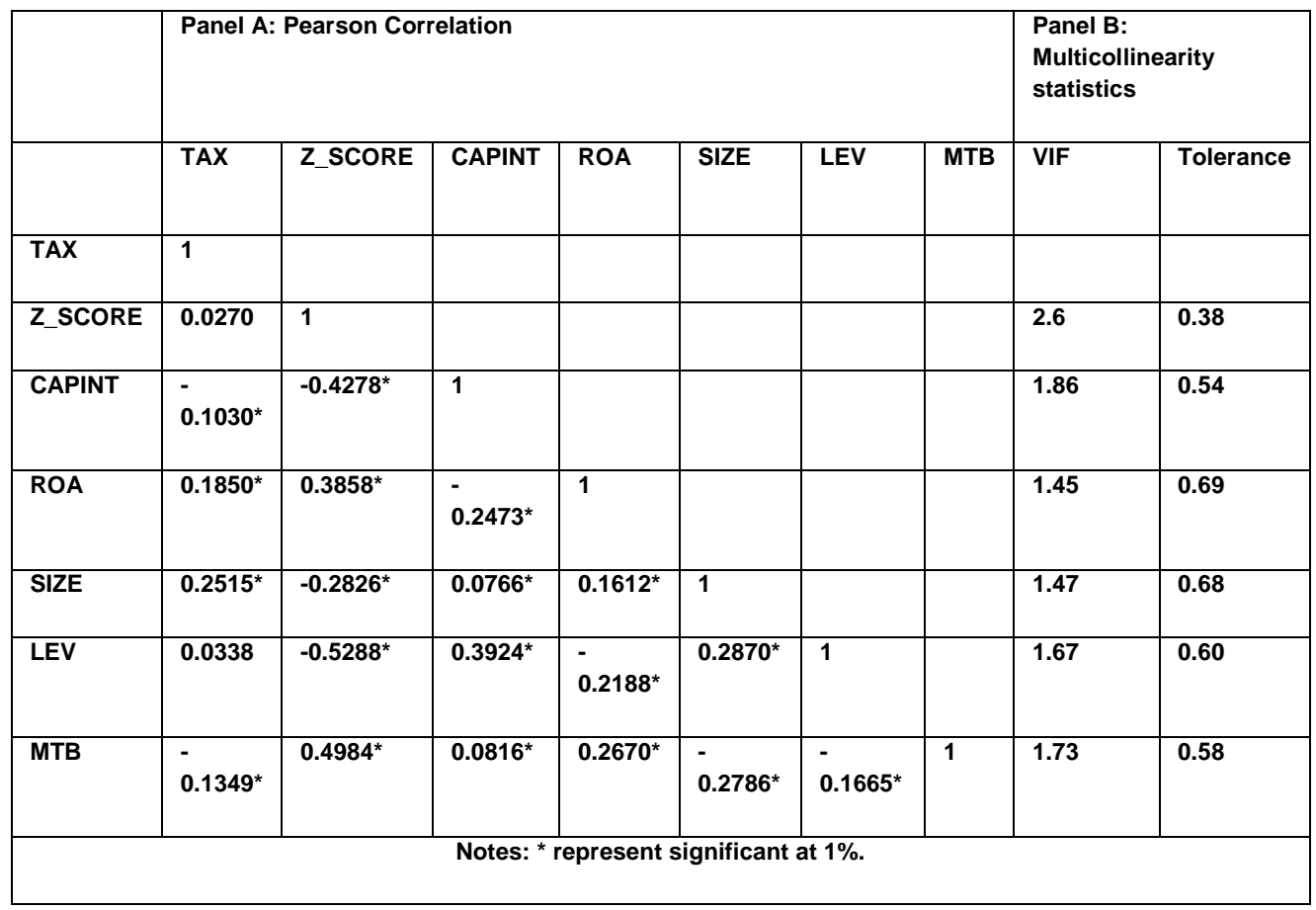

\subsection{Discussion}

Table VII depicts the results of the regression analysis. The results indicate the significant effect of the examined determinants, namely financial distress, capital intensity, profitability and firm size on the tax avoidance at significance level of $1 \%$ since the $p$-value $<0.000$. Based on 672 firm-year observations, the value of R-square is $17 \%$. This implies that the examined factors interpret $17 \%$ of the change in the pattern of the tax avoidance for the Egyptian listed companies. 
Tax Avoidance Practises and Firm-specific Characteristics:

Table VII The Regression Result

\begin{tabular}{|c|c|c|c|c|}
\hline \multirow[t]{2}{*}{ Variables } & \multicolumn{4}{|c|}{ Results } \\
\hline & Coef. Std. & Standard Errors & $\mathbf{t}$ & $\mathbf{P}>|\mathbf{t}|$ \\
\hline \multicolumn{5}{|c|}{ Independent Variables } \\
\hline Z_SCORE & 0.02044 & 0.007053 & 2.9 & $0.004 *$ \\
\hline CAPINT & 0.081205 & 0.058799 & 1.38 & 0.168 \\
\hline ROA & 0.479837 & 0.186008 & 2.58 & $0.010 *$ \\
\hline SIZE & 0.110357 & 0.019552 & 5.64 & $0.000 *$ \\
\hline \multicolumn{5}{|c|}{ Control variables } \\
\hline LEV & 0.277278 & 0.214846 & 1.29 & 0.197 \\
\hline MTB & 0.02007 & 0.005424 & -3.70 & $0.001 *$ \\
\hline $\begin{array}{l}\text { Year and } \\
\text { industry effect }\end{array}$ & \multicolumn{4}{|l|}{ Controlled } \\
\hline Number of Obs. & \multicolumn{4}{|l|}{672} \\
\hline P. Value & \multicolumn{4}{|l|}{0.000} \\
\hline R-Squared & \multicolumn{4}{|l|}{0.17} \\
\hline \multicolumn{5}{|c|}{ Note: $* \mathrm{p}<.1$} \\
\hline
\end{tabular}

As expected, the results reveal a significant and positive relationship between Z_SCORE and TAX at significance threshold of $1 \%$ where $\beta_{1=0.020}$ and $\mathrm{p}$-value $<0.004$, accordingly $\mathrm{H}_{1}$ is accepted. This finding implies that the higher the financial distress situations companies face, the higher their tendency to engage in tax avoidance practices. Similar results are also reported by Richardson et al.(2015a) and Dang and Tran, (2021). A possible justification could be driven from Brondolo (2009)'s work that argue that during the economic deficiencies periods, tax agencies are suffering from higher risk of companies' tax non-compliance and greater taxpayers' expectation for support to resolve the potential budget distress. In addition, 64 
in the case of the tightness or the unavailability of credit avenues, the financially distress companies may make use of the tax avoidance as a possible technique toward financing their operations. Furthermore, during the financial crisis periods, companies with bad financial situations would squeeze their cash outlays in investment, technology utilized, and employment compared to other companies with good financial position (Campello et al., 2010). Similarity, Richardson et al. (2015a) provide an empirical evidence based on Australian sample that the rate of tax avoidance is augmented during the highly tension period such as the global financial crisis in 2008. In addition, within such crisis periods, financially constrained companies are engaged in tax planning strategies that may erode their tax payment and boost their cash inflows (Richardson et al. 2015a). Accordingly, since the Egyptian listed companies face instability in their earning or encounter lower credit rating predication during the sample period from 2015 to 2018 as the result of the local economic and political events as well as the global crisis of the pandemic covid-19, the positive and significant association between financial distress and tax avoidance seems reasonable for the Egyptian listed companies.

Regarding the relationship between CAPINT and TAX, the results in Table VII reveals a positive but non-significant association at the significance level of $1 \%$ in such $\beta_{2=0.081}$ and $p$-value $<0.168$, thus rejecting $\mathrm{H}_{2}$. Similar results are reported by Maulana et al. (2018), Monika and Noviari (2021) and Ulfa et al. (2021). The logic rationalization for this result could be explained from two perspectives as follows. First, companies with higher capital intensity ratio would not resort to tax avoidance activities to erode their tax payment since their high figures of fixed asset and the corresponding depreciation expenses would mitigate their tax burden in legitimate way (Sonia and Suparmun, 2019). Similarity, Rifai and Atiningsih (2019) indicate that the higher the companies' investment in fixed assets, the higher the depreciation expenses and the lower the tax burden they bear. Thus, the capital intensity should not be associated with tax avoidance activities as long as the depreciation expenses themselves 
would guarantee lower taxable income and in turn lower tax rate. second, Ulfa et al. (2021) argue that the non-association between capital intensity and tax avoidance is because companies usually utilize their fixed assets in their operation and not for the sake of getting lower tax burden as an act toward tax avoidance.

Similar to expectation, ROA is positively and significantly associated with TAX $\left(\beta_{3=0.480}\right.$ and $p$-value $<0.010$, thus accepting $\mathrm{H}_{3}$ at significance level of $1 \%$. Accordingly, the higher the ROA, the more likely that companies would avoid paying their taxes. Likewise, Lanis and Richardson (2012); Kim and Im (2017) and Abd-Elmageed and Ashour (2021) report also similar association between the companies' profitability and tax avoidance. This result is consistent with the agency theory notion of self-interest incentives for both the principle and the agent. While the tax authority strives to maximize the tax revenues, the companies' management is also attempted to magnify their earning income. As long as, the higher profit is accompanied with bigger tax burden companies should bear, it is expected that companies would resort to the tax avoidance activities to maintain higher earnings figures and cash flows (Kalbuana et al. 2020, Darsani and Sukartha, 2021). Correspondingly, Richardson et al. (2015a) argue that companies' managers may exploit any ambiguity or misinterpretations of the tax laws to mitigate the taxable income. Under the temptation of the considerable cost saving accompanied with tax avoidance activities, managers may be urged toward acting aggressively against the tax policy (Richardson et al., 2015a).

At significance level of $1 \%$, the results also reveal that SIZE positively determine the tax avoidance activities $\left(\beta_{4=0.110}\right.$ and $p$-value $\left.<0.000\right)$, thus accepting H4. Similarly, Richardson et al. (2015a), Irianto et al. (2017) and Salhi et al. (2020) report a significant positive association between the companies' size and tax avoidance. In addition, Deef et al., (2021) provide an empirical evidence based on a sample of Egyptian listed companies that large size companies are engaged in tax avoidance practise. A possible justification in this regard is that since the companies' managers act as the 
agent against the tax authorities' objectives, they would exploit any possible avenues to save any deductible amounts from the achieved profit. Thus, managers will always pursue to avoid the tax payment. While the small size companies cannot ideally manage their tax planning because of the dearth of the competent managers, the bigger size companies are more capable to conduct their tax management plan in the light of the availability of highly qualified and skilled managers (Badertscher et al., 2013; Ulfa et al., 2021). Thus, it seems reasonable that the companies' size has positive influence of the tax avoidance activities.

With respect to the control variables, results indicate that there is nonsignificant association between LEV and TAX, suggesting that the tax avoidance activities are not affected by companies' borrowing policies $\left(\beta_{5=0.277}\right.$ and $p$-value $\left.<0.197\right)$. Similar results are reported by Lanis and Richardson (2012) Darsani and Sukartha, (2021). The ratio of the long-term debt to total assets implies the companies' ability to cover their long-term borrowing obligations from the available asset. High debt borrowing is accompanied with higher interest expenses and in turn lower taxable income the companies should pay. According to Badertscher et al. (2013), companies with greater leverage may be redundant toward practicing the tax avoidance schemes because of the tax benefits they utilize from the debt financing. Table $\mathrm{V}$ shows that on average the Egyptian companies demonstrate a lower leverage rate of $4 \%$. This minor figure of leverage indicates the lower interest expense in the manner that may not permit the Egyptian companies to make any tax avoidance activities through debt financing. MTB is found to be positively associated with TAX at significance level of $1 \%\left(\beta_{6=0.020}\right.$ and $p$-value $\left.<0.001\right)$. Similar result is reported by Lanis and Richardson (2012). Accordingly, the higher the growth opportunities companies have, the higher the incentives toward tax avoidance. This result may be reasonably since the companies' expansion plan require them to save sufficient money to finance their investments. 


\section{Conclusion}

Tax avoidance is one the biggest challenges that face the Egyptian tax authority. Since the tax revenues contribute to a great extent in maintaining the economic reforms endeavours initiated by the Egyptian government, the tax regulators pay more attention to the different factors determine the tax avoidance activities. The aim of the study is to address the main determinant of tax avoidance with respect to the firm specific characteristics of the Egyptian listed companies for the period between 2015 to 2017. Based on 672 firm year observation, the study provides empirical evidence of the effect of specific companies' characteristics on the diffusion of tax avoidance practise in the Egyptian context. The study reveals that the companies' financial distress, profitability, size and growth opportunities positively influence the rate at which companies avoid paying their taxes. in contrast, the study indicates that neither the capital intensity nor the leverage ratio is associated with the tax avoidance practice.

The study contributes to the extant literature on two aspects as follows. First, it provides empirical evidence of the main determinates of tax avoidance in Egypt. It alerts the Egyptian government and other related regulatory bodies to the association between the characteristics of the Egyptian listed companies and their tendency toward avoiding the tax payment. This evidence should stimulate the tax regulators to take corrective remedies to handle the weakness or gab in corporate tax laws that Egyptian companies may exploit based on their unique characteristics. Second, subject to the crowded political and economic events surround the Egyptian market in the last period (Abdelfattah and Aboud, 2020; Aladwey, 2021), the study provides a clear picture of the firm specific factors that determine the change of the tax avoidance rate within the period from 2015 to 2018. This picture would help the Egyptian government endeavours toward tackling tax avoidance and enhancing more transparent tax environment.

The limitation of the study may open the door future research avenues as follows. First, the study examines the main determinants of tax avoidance in Egypt. While tax avoidance may be conducted within formal reforms, the tax evasion may unethically help companied to erode their governmental 
resources, especially in developing countries (Dang and Hang (2021). Accordingly, it would be interesting if other researchers consider the implications and determinants of tax evasion within the Egyptian context. Second, it would be also interesting if future studies examine the association of firm specific factors other than those examined in this study that may affect the tax avoidance practise, such as liquidity, market share, operating cash flow and growth rate. Third, according to (Altman and Hotchkiss, 2006) and Richardson et al. 2015a, financial distressed companies are passing four consecutive stages, namely failure, insolvency, bankruptcy and default. Future research could consider the association of each stage of financial distress on the management' $s$ attitudes toward tax avoidance.

\section{References}

Abdelfattah T, Aboud A, Tax avoidance, corporate governance, and corporate social responsibility: The case of the Egyptian capital market, Journal of International Accounting, Auditing and Taxation (2020), doi: https://doi.org/10.1016/j.intaccaudtax.2020.100304

Abd-Elmageed, Mohamed Hassan and Ashour, Bassant Abdelmordy (2021) Are Tax Avoidance, Corporate Social Responsibility and Financial Performance Affecting Firm Value in the Egyptian Listed Companies? Accounting Thoughts Alexandria University, 25(1), pp.866-899.

Aladwey, L.M.A. (2021), "The effect of equity ownership structure on nonconditional conservatism: an empirical study based on listed companies in Egypt", Journal of Financial Reporting and Accounting, Vol. ahead-of-print No. ahead-of-print. https://doi.org/10.1108/JFRA-04-2020-0104

Aldemrdash (2020), Combating tax avoidance for digital economy activities in the Egyptian and Saudi tax systems by focusing on the income tax and value-added laws, Journal of political and economic studies, 6(8), Autumn, pp.1-141,DOI: $) \cdot$. I $7 \cdot \wedge / J D L .2020 .126750$ 
Ali, Taghreed; El-dawy, Esraa; Tawab, Yasmin and Mahdi, Noor (2017) "Taxes and Economic Development in Egypt, Democratic Arab Center, https://democraticac.de/?p=47188

Badertscher, Brad; Katz, Sharon and Rego, Sonja (2013) The separation of ownership and control and corporate tax avoidance, Journal of Accounting and Economics, 56, pp. 228-250.

Bayar, Onur; Huseynov, Fariz and Sardarli, Sabuhi (2018) Corporate Governance, Tax Avoidance, and Financial Constraints, Financial Management, Fall, pp. 651 - 677.

Brondolo, J., 2009. Collecting Taxes During an Economic Crisis: Challenges and Policy Options. IMF staff position note (SPN/09/17), pp. 138, (Available at: www.imf.org/ external/pubs/ft/spn/2009/spn0917.pdf).

Campello, M., Graham, J., Harvey, C., (2010) The real effects of financial constraints: evidence from a financial crisis, Journal of Financial Economics, 97 (3), pp. 470-487.

Dakhli, A. (2021), "The impact of ownership structure on corporate tax avoidance with corporate social responsibility as mediating variable", Journal of Financial Crime, Vol. ahead-of-print No. ahead-of-print. https://doi.org/10.1108/JFC-07-2021-0152

Dang, Van Cuong and Tran, Xuan Hang (2021) The impact of financial distress on tax avoidance: An empirical analysis of the Vietnamese listed companies, Cogent Business \& Management, 8(1), 1953678, DOI: $10.1080 / 23311975.2021 .1953678$

Darsani, Putu Asri and Sukartha, Made (2021) The Effect of Institutional Ownership, Profitability, Leverage and Capital Intensity Ratio on Tax Avoidance, American Journal of Humanities and Social Sciences Research (AJHSSR), Vol.5, Issue 1, pp-13-22.

Dougherty, Christopher (2011) Introduction to Econometrics, $4^{\text {th }}$ edn, Oxford University Press. 
Dyreng, S., M. Hanlon, and E. Maydew, 2008, "Long-Run Corporate Tax Avoidance," Accounting Review, 83, 61-82.

Eisenhardt, K.M. (1989), "Agency theory: an assessment and review", Academy of Management Review, 14 (1), pp. 57-74.

El-Masry, A.A. (2010), "Corporate governance, ownership structure and firm performance of Egyptian listed companies", Corporate Ownership and Control, 8 (1), pp. 535-551.

Elnaggar, Yasser (2020) Egypt and COVID-19: The Day After, Rethinking Egypt's Economy, edited by Mabrouk, Mirette F., https://www.mei.edu/sites/default/files/2020-

10/Rethinking\%20Egypt\%27s\%20Economy.pdf

Elsayed, K. and Wahba, H. (2013), "Reinvestigating the relationship between ownership structure and inventory management: a corporate governance perspective", International Journal of Production Economics, 143 (1), pp. 207-218.

Gad, Mohamed; Seif, Sarah; Kassab, Bisan and Magdy, Noha (2019) Taxes for Whom, Al-Maraya House for Cultural Production.

Habbash, M.; Sindezingue, C. and Salama, A. (2013) The Effect of Audit Committee Characteristics on Earnings Management: Evidence from the United Kingdom. International Journal of Disclosure and Governance,10: 13-38. doi: 10.1057/jdg.2012.2

Habib, Ahsan; D' Costa, Mabel; Huang, Hedy Jiaying; Bhuiyan, Md. Borhan Uddin and Sun, Li (2020) Determinants and consequences of financial distress: review of the empirical literature, Accounting \& Finance, 60,pp.1023-1075

International Monetary Fund (IMF) (2020), World Economic Outlook: The Great Lockdown, Washington, DC, April. available online at www.imf.org/en/Publications/WEO/Issues/2020/04/14/weo-april-2020

Irianto, B.S., Sudibyo, Y.A. andWafirli, A. (2017), "The influence of profitability, leverage, firm size and capital intensity towards tax avoidance", International Journal of Accounting and Taxation,5 (2), pp. 33-41. 
Kalbuana, Nawang; Solihin; Saptono; Yohana and Yanti, Devia Rahma (2020) The Influence of Capital Intensity, Firm Size, And Leverage on Tax Avoidance on Companies Registered In Jakarta Islamic Index (JII) Period 2015-2019, International Journal of Economics, Business and Accounting Research (IJEBAR), 4 (3), pp.272-278.

Kim, J. H., and Im, C. C. (2017). The Study on The Effect and Determinants Of Small - And Medium-Sized Entities Conducting Tax Avoidance. Journal of Applied Business Research (JABR),33(2), 375-390. https://doi.org/10.19030/jabr.v33i2.9911

Lanis, R. and Richardson, G. (2012), "Corporate social responsibility and tax aggressiveness: an empirical analysis", Journal of Accounting and Public Policy,31 (1), pp. 86-108.

Lanis, R. and Richardson, G. (2015), "Is corporate social responsibility performance associated with tax avoidance?", Journal of Business Ethics, 127 (2), pp. 439-457.

Lietz, Gerrit (2013) Tax Avoidance vs. Tax Aggressiveness: A Unifying Conceptual Framework, Available at SSRN: https://ssrn.com/abstract=2363828 or http://dx.doi.org/10.2139/ssrn.2363828

Maulana; Marwa, Taufiq and Wahyudi, Tertiarto (2018) The Effect of Transfer Pricing, Capital Intensity and Financial Distress on Tax Avoidance with Firm Size as Moderating Variables, Modern Economics,10, pp. 122128. DOI: https://doi.org/10.31521/modecon.V11(2018)-20.

Monika, Christin Maria and Noviari, Naniek (2021) The Effects of Financial Distress, Capital Intensity, and Audit Quality on Tax Avoidance, American Journal of Humanities and Social Sciences Research (AJHSSR), 5(6), pp-282-287.

Napitupulu, I.H., Situngkir, A. and Edelia, A. (2019), "Triggers of tax avoidance practices in Indonesia", International Journal of Economics, Business and Management Research, (3)11, pp.1-7. 
Park, H.M. (2011), "Practical guides to panel data modelling: a step-by-step analysis using stata", Tutorial Working Paper-Graduate School of International Relations, International University of Japan, available at: www.iuj.ac.jp/faculty/kucc625/method/panel/panel_iuj.pdf

Prawati; Levana Dhia and Hutagalung, Jesica Pinta Uli (2020) The effect of capital intensity, executive characteristics, and sales growth on tax avoidance, Journal of Applied Finance and Accounting, 7(1), April pp. 1979 - 6862.

Ramadan, Maha Mohamed (2017) "An Investigation of the effect of the quality of accounting reports on financial distress in Egyptian Listed Firms Evidence from Emerging Markets", Accounting Thought, Article 11, 21, (8) Autumn, pp.40-84, Ain Shams University, DOI:10.21608/ATASU.2017.42516

Raweh, N.A.M; Abdullah, A.A., Kamardin, H. H. and Malek, M. (2021) Industry expertise on audit committee and audit report timeliness. Cogent Business and Management, 8:1, 1920113, DOI: 10.1080/23311975.2021.1920113

Richardson, Grant; Lanis, Roman and Taylor, Grantley (2015b) "Financial distress, outside directors and corporate tax aggressiveness spanning the global financial crisis: An empirical analysis", Journal of Banking \& Finance, 52, pp. 112-129

Richardson, Grant; Taylor, Grantley and Lanis, Roman (2015a) "The impact of financial distress on corporate tax avoidance spanning the global financial crisis: Evidence from Australia", Economic Modelling, 44, pp.44-53.

Rifai, A., \& Atiningsih, S. (2019). Pengaruh Leverage, Profitabilitas, Capital Intensity, Manajemen Laba Terhadap Penghindaran Pajak. ECONBANK: Journal of Economics and Banking, 1(2), 135-142. https://doi.org/10.35829/econbank.v1i2.48

Salhi, B., Riguen, R., Kachouri, M. and Jarboui, A. (2020), "The mediating role of corporate social responsibility on the relationship between governance and tax avoidance: UK common law versus French civil law", 
Social Responsibility Journal, Vol. 16 No. 8 , pp. $1149-1168$. https://doi.org/10.1108/SRJ-04-2019-0125

Shahwan, Tamer Mohamed (2015) The effects of corporate governance on financial performance and financial distress: evidence from Egypt, Corporate Governance International Journal of Business in Society, 15(5), pp. 641-662.

Shahwan, Tamer Mohamed and Habib, Ahmed Mohamed (2020) Does the efficiency of corporate governance and intellectual capital affect a firm's financial distress? Evidence from Egypt, Journal of Intellectual Capital,21(3), pp. 403-430, DOI 10.1108/JIC-06-2019-0143

Sonia, S., and Suparmun, H. (2019). Factors influencing tax avoidance. In 5th Annual International Conference on Accounting Research (AICAR 2018).

Sugeng; Prasetyo, Eko and Zaman, Badrus (2020) "Does capital intensity, inventory intensity, firm size, firm risk, and political connections affect tax aggressiveness?", JEMA: Jurnal Ilmiah Bidang Akuntansi dan Manajemen, 17(1), pp. 78-87

Tilehnouei, Mostafa Hashemi; Esfahani, Sedigheh Tootian and Soltanipanah, Somayeh (2018) Investigating the Effect of Financial Distress on Tax Avoidance during the Global Financial Crisis in Companies Listed on Tehran Stock Exchange, International Journal of Finance and Managerial Accounting, 3 (9), Spring, pp.41-51.

Trisanti, Theresia (2021) Determination Causes of Tax Avoidance on Indonesian Manufacturing Firms with Capital Intensity as Intervening Variables, WAHANA: Jurnal Ekonomi, Manajemen dan Akuntansi, 24 (1), pp.1-16.

Ulfa, Evi Khusnita; Suprapti, Eny and Latifah, Sri Wahjuni (2021) The Effect of CEO Tenure, Capital Intensity, And Company Size on Tax Avoidance, Jurnal Reviu Akuntansi dan Keuangan, 11 (1), p. 77-86. 